\title{
Effect of Summer Supplementary Feeding on Cattle Performance in Low Rainfall Grassland Savanna, South Darfur, Sudan
}

\author{
Abu Bakr Omer Ismail1, Yousif Rizggalla Sulaiman1, Faisal Awad Ahmed², \\ Hafiz Abdalla Mohamed Ali ${ }^{*}$ \\ ${ }^{1}$ Department of Animal Production, College of Natural Resources and Environmental Studies, University of Juba, \\ Khartoum, Sudan \\ ${ }^{2}$ Ministry of Science and Technology, Khartoum, Sudan \\ Email: hafizabdo@hotmail.com
}

Received 8 July 2014; revised 25 August 2014; accepted 1 September 2014

Copyright (C) 2014 by authors and Scientific Research Publishing Inc.

This work is licensed under the Creative Commons Attribution International License (CC BY). http://creativecommons.org/licenses/by/4.0/

(c) (i) Open Access

\section{Abstract}

In a tropical ranch of animal production, which was divided by fire lines into 20 equal grazing paddocks of one mile square each, a grazing experiment was conducted as controlled rotational grazing with forty-five (45) cross-bred Sudanese improved Baggara cattle which were divided into four feeding systems (groups). A drop in condition scores of the farm cattle stock herd was treated during dry summer by supplementary feeding with four types of supplements to investigate the changes in average body weight changes, heart girth and condition scores, through dry summer, wet summer and winter seasons. The results showed that, animals of group three (G3) which supplemented with groundnut cake performed better in all body parameters under study when compared with group one (G1) and group two (G2) being supplemented with groundnut haulm, Stover respectively and group four (G4) which was kept under natural grazing as control group (Natural grazing alone) which reveals the worse body measurement traits performance under study. The effect of seasonal changes showed a significant difference $(P<0.05)$ between the seasons in average body weight in groundnut cake supplements both in dry and wet summer obtained better average body weight (162.53 $\mathrm{Kg}$ and $174.56 \mathrm{Kg}$ respectively) than in groundnut haulm (in dry and wet summer $-143.60 \mathrm{Kg}$ and $163.50 \mathrm{Kg}$ respectively), Stover supplements and natural grazing (controlled) groups. The results also showed that, the heart girth and condition score were significantly different $(P<0.05)$ between the treatments in wet summer and winter. While showing no significant difference between the treatments in dry summer, group supplemented with groundnut cake during the dry summer reported better performance in condition scores than other groups.

\footnotetext{
${ }^{*}$ Corresponding author.
}

How to cite this paper: Ismail, A.B.O., et al. (2014) Effect of Summer Supplementary Feeding on Cattle Performance in Low Rainfall Grassland Savanna, South Darfur, Sudan. Open Journal of Animal Sciences, 4, 337-343. 


\section{Keywords}

\section{Body Weight, Condition Score, Groundnut Cake, Groundnut Haulm, Heart Girth and Stover}

\section{Introduction}

Most of the tropical pasture grassland is infertile and large portions occur in dry/arid areas, where there are limited options for improving pasture and animal nutrition [1]. Native pastures are usually dominated by course grasses, that are only palatable and nutritious when young, and native legumes are scarce. Animal weight gains are usually high in the early wet season when grasses are young, but in early dry season when pasture growth stops and quality declines, animal loss weight [2].

Properly managed grassland in tropical zones has the potential to improve forage quality and increase herbage yields several-folds over that of naturalized grazing lands. The most important factors in cattle feeding are the quality of energy-supplying constituents, total digestible nutrients and total digestible proteins [3].

A $400 \mathrm{Kg}$ animal requires about $0.4 \mathrm{Kg}$ of total protein daily, for maintenance. In addition to maintenance requirements, $0.5 \mathrm{Kg}$ of protein is needed per $\mathrm{Kg}$ of live weight gain. The percentage protein required in the feed of the most cattle can be provided by herbage of improved pastures during the favorable season of plant growth [4].

It is useful to quantify the extends to which cattle are affected by either nutrition, disease or other environmental factors, especially when large fluctuations in the quantity and quality of available forage occur, as they do in seasonally dry tropical and sub-tropical areas. Weight per se does not reflect an animal's condition: an animal with a large frame may have a higher body weight when at a low level of body reserves [5] than another animal with a smaller frame but abundant reserves.

For monitoring of individual animal seasonal weight changes, usually the measuring of changes in weight or heart girth techniques is used, especially in areas where it is difficult to establish a scale weighing balance [6]. Condition scoring provides a quick, cheap and easy method of comparing herds of cattle or individual animals under different management systems, experimental treatments, seasons or environment [7]. A highly positive correlation existed in condition score among animals of the same age, sex, live weight and carcass weight [8]. In the law rainfall grassland savanna of western Sudan, a drastic drop in grass quality especially during the dry season usually resulted in the body weight lost and thus animal emaciation, thus against this fact, this study was formulated to draw the effect supplementary feeding on cattle performance raised on dry summer grassland feeding in south Darfur.

\section{Materials and Methods}

\subsection{Site of Study}

The experiment was conducted at Ghazal Gawazat Range and Animal Production Research Station in the belt of Western Sudan, South Darfur (Latitude $11^{\circ} 28^{\prime} \mathrm{N}$; Longitude $25^{\circ} 57^{\prime} \mathrm{E}$ at an altitude of $485 \mathrm{~m}$ above sea level). The year is divided into three seasons: summer (March to June), autumn (July to October) and winter (November to February).

\subsection{Experimental Animals}

Forty-five (45) cross-bred Baggara cattle (zebu type) herd consisting of bulls, heifers, dry and milking cows and early weaned calves of various age were used in this experiment. The animals were born and raised at the research station, with a good health condition. They were randomly grouped into four dry summer supplementary feeding systems: Groundnut haulm (G1), Stover (G2), Groundnut cake (G3) and controlled group (G4) with no supplementary feeding allowance. These supplements were offered in one evening meal at a rate of $1.5 \mathrm{Kg} / \mathrm{head} /$ day, $2.0 \mathrm{Kg} / \mathrm{head} /$ day and $1.0 \mathrm{Kg} / \mathrm{head} /$ day for G1, G2 and G3 respectively.

They were divided into four (4) experimental groups each of eleven (11) to twelve (12) animals. Each group according to sex consists of male (M) and female (F) animals of different age-grouops. According to age, the animals were grouped as Zero (0) for mature animals (2.5 - 5 years), One (1) as suckling calf, Two (2) as wean- 
ers, Three (3) as yearlings and Four (4) as 1 - 2.5 years age groups.

Each group was introduced to a grazing paddock from 8:00 am to 5:00 pm for daily grazing. Each group remained in the corresponding paddock for four months. The grazing was started on the first of March 2004 and completed in June 2005. The total grazing period was 16 months (64 weeks), starting with an adaptation period that lasted for two weeks.

Heart girth, body weight and height were monthly measured with the hand using scaled measuring tape. Monthly measurements and condition scores were carried according to the method described by [5] were recorded.

\subsection{Statistical Analysis}

The experimental data analysis were performed using SPSS software [9] and the effects of supplementary feeding (summer, autumn and winter) on body performance were subjected to Two-ways Analysis of Variance, and the treatment means were tested for significance [10].

\section{Results}

The effect of supplementary feeding and type of sex is on body weight (Table 1). The final live body weight and weight changes (Kg per month) was significantly $(\mathrm{P}<0.05)$ different between the treatments. Group (1) supplemented with groundnut cake obtained the best final live body weight (170.48 Kg) then group (2) supplemented with groundnut haulms, (G3) Stover and (G4) natural grazing, obtained a final live body weights of 159.75, 156.83 and 150.42 Kilograms respectively.

Also live body (changes/Kg/month) for groundnut cake $(38.18 \mathrm{Kg})$ was significantly $(\mathrm{P}<0.05)$ better than groundnut haulms $(24.08 \mathrm{Kg})$, Stover $(20.25 \mathrm{Kg})$ and natural grazing $(19.17 \mathrm{Kg})$. Females were significantly (P $<0.05)$ performed better than males in final and body weight changes. Also the results revealed that there was an interaction of feeding systems and type of sex in final body weight (Table 1).

The results showed that, there was a significant difference $(\mathrm{P}<0.05)$ in body length, height, leg length and dewlap length between the four treatments. G3 treated with groundnut cake and G4 which was kept under natural grazing performance was better far in these parameters than G1 and G2 supplemented with groundnut haulm and Stover respectively (Table 2). On the other hand, heart girth, neck length and condition score showed no significance differences among the four groups of supplements, but the treatment effect was significantly different $(\mathrm{P}<0.05)$ in type of sex. Female animals showed a better performance in the performance traits under investigation, that is, treatment sex interaction (Table 2).

Also the results showed a significant differences $\mathrm{P}(<0.001)$ in all the trait performance under study between type of sex and age groups. Females significantly reported better body measurements in terms of heart girth

Table 1. Effect of supplementary feeding and type of sex on body weight changes.

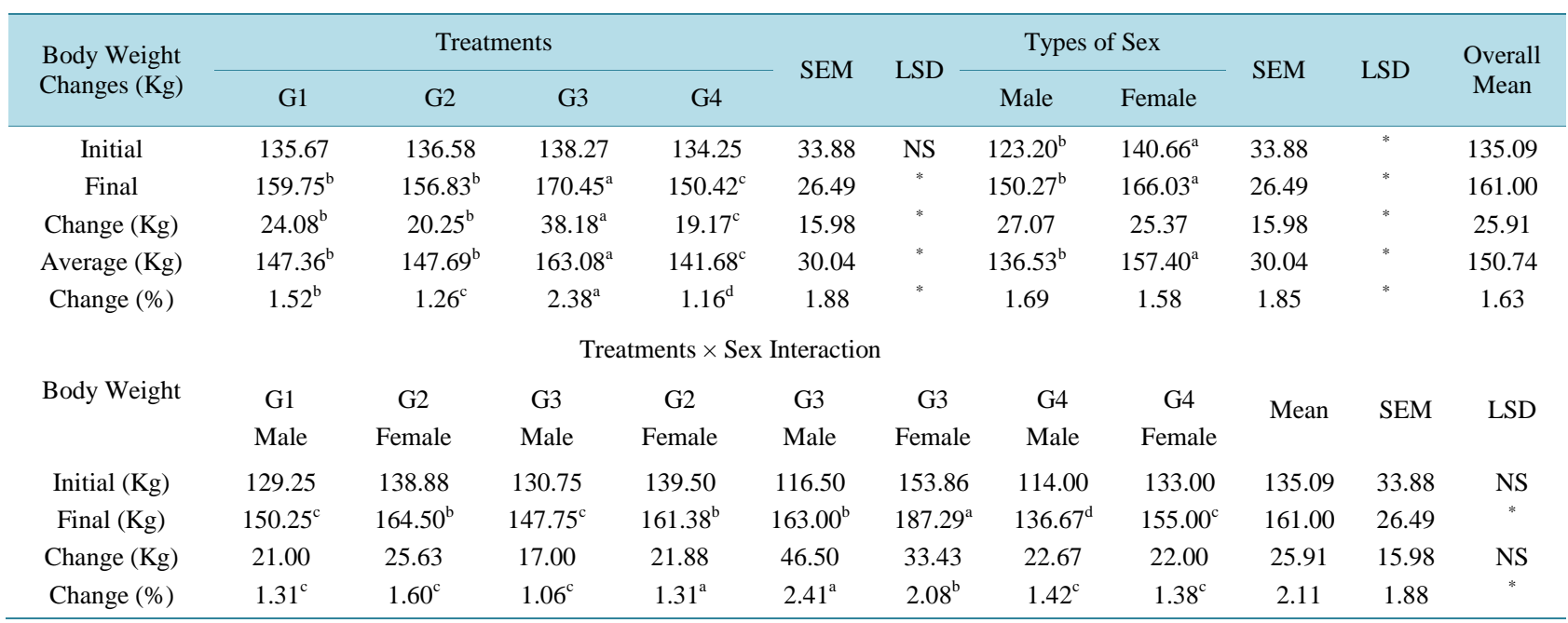

a, b, c and d = Values on the same row with different superscripts differ significantly $(\mathrm{P}<0.05)$. SEM = Standard Error. NG = Natural Grazing. GNC = Ground Nut Cake. LSD = Least Significant. NS = Not Significant Difference. ${ }^{*}=$ Significant at $(\mathrm{P}<0.05)$. G1 = Groundnut Haulm, G2 = Stover, G3 = Groundnut Cake, G4 = Natural Grazing. 
(115.51 cm), body length $(92.82 \mathrm{~cm})$ and height $(111.51 \mathrm{~cm})$ than males which reported a heart girth of (111.16 $\mathrm{cm})$, a body length of $(85.01 \mathrm{~cm})$ and a height of $105.88 \mathrm{~cm}$ (Table 3). On the other hand, age groups with re-

Table 2. Body traits performance on type of sex.

\begin{tabular}{|c|c|c|c|c|c|c|c|c|c|c|c|}
\hline \multirow{2}{*}{ Performance Traits (cm) } & \multicolumn{4}{|c|}{ Treatments } & \multirow{2}{*}{ SEM } & \multirow{2}{*}{ LSD } & \multicolumn{2}{|c|}{ Sex } & \multirow{2}{*}{$\begin{array}{c}\text { Overall } \\
\text { Mean }\end{array}$} & \multirow{2}{*}{ SEM } & \multirow{2}{*}{ LSD } \\
\hline & G1 & G2 & G3 & G4 & & & Male & Female & & & \\
\hline Heart Girth & 113.62 & 113.43 & 114.66 & 112.61 & 10.99 & NS & $111.16^{\mathrm{b}}$ & $115.96^{\mathrm{a}}$ & 10.99 & 113.57 & $* *$ \\
\hline Body Length & $82.74^{\mathrm{b}}$ & $84.65^{\mathrm{b}}$ & $95.37^{\mathrm{a}}$ & $94.39^{\mathrm{a}}$ & 13.59 & ** & $85.41^{\mathrm{b}}$ & $92.82^{\mathrm{a}}$ & 13.59 & 88.94 & *** \\
\hline Height & $108.57^{\mathrm{b}}$ & $108.82^{\mathrm{b}}$ & $116.42^{\mathrm{a}}$ & $109.68^{\mathrm{b}}$ & 11.43 & *** & $105.37^{\mathrm{b}}$ & $111.51^{\mathrm{a}}$ & 11.43 & 105.71 & *** \\
\hline Leg Length & $65.14^{\mathrm{b}}$ & $64.35^{\mathrm{b}}$ & $69.79^{\mathrm{a}}$ & $67.74^{\mathrm{a}}$ & 7.03 & ** & $64.39^{\mathrm{b}}$ & $68.69^{\mathrm{a}}$ & 7.03 & 66.56 & $* * *$ \\
\hline Neck Length & 39.90 & 39.35 & 40.29 & 41.08 & 5.03 & NS & $39.16^{\mathrm{b}}$ & $41.49^{\mathrm{a}}$ & 5.03 & 40.32 & ** \\
\hline Dewlap Length & $61.17^{\mathrm{b}}$ & $62.39^{\mathrm{b}}$ & $66.87^{\mathrm{a}}$ & $64.13^{\mathrm{a}}$ & 10.34 & $* *$ & $60.18^{\mathrm{b}}$ & $66.79^{\mathrm{a}}$ & 10.34 & 63.49 & *** \\
\hline Condition Score & 0.69 & 0.71 & 0.72 & 0.70 & 0.16 & NS & 0.70 & 0.70 & 0.16 & 0.71 & NS \\
\hline \multicolumn{12}{|c|}{ Treatments $\times$ Sex Interaction } \\
\hline Performance Traits (cm) & G1 & G2 & G2 & 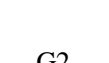 & G3 & G3 & G4 & G4 & SEM & $\begin{array}{c}\text { Overall } \\
\text { Mean }\end{array}$ & LSD \\
\hline & Male & Female & Male & G2 & Male & Female & Male & Female & & & \\
\hline Body Weight (Kg) & $137.130^{\mathrm{b}}$ & $149.48^{\mathrm{d}}$ & $138.403^{b}$ & $152.33^{c}$ & $142.52^{\mathrm{e}}$ & $174.83^{\mathrm{a}}$ & 125.36 & $155.40^{\mathrm{b}}$ & 30.04 & 107.44 & ** \\
\hline Heart Girth & $109.87^{c}$ & $115.70^{\mathrm{b}}$ & $112.33^{\mathrm{b}}$ & $115.44^{\mathrm{b}}$ & $115.16^{\mathrm{b}}$ & $113.15^{\mathrm{b}}$ & $101.69^{c}$ & $118.32^{\mathrm{a}}$ & 10.99 & 113.57 & $* *$ \\
\hline Body Length & $77.33^{\mathrm{d}}$ & $85.74^{\mathrm{c}}$ & $83.73^{\mathrm{c}}$ & $93.60^{\mathrm{b}}$ & $93.60^{\mathrm{b}}$ & $98.77^{\mathrm{b}}$ & $80.31^{\mathrm{d}}$ & $102.48^{\mathrm{a}}$ & 13.59 & 88.94 & $* *$ \\
\hline Height & 105.93 & 106.93 & 101.07 & 113.40 & 113.40 & 122.23 & 102.46 & 113.44 & 11.43 & 108.71 & NS \\
\hline Leg Length & 62.53 & 66.59 & 67.40 & 67.42 & 69.00 & 71.31 & 62.31 & 70.56 & 7.03 & 66.56 & NS \\
\hline Neck Length & 38.20 & 40.85 & 38.90 & 40.11 & 40.12 & 43.54 & 39.00 & 42.16 & 5.03 & 40.32 & NS \\
\hline Dewlap Length & 55.67 & $64.22^{\mathrm{b}}$ & $60.67^{\mathrm{b}}$ & $60.67^{\mathrm{b}}$ & $65.20^{\mathrm{b}}$ & $70.07^{\mathrm{a}}$ & $54.62^{\mathrm{C}}$ & $69.08^{\mathrm{a}}$ & 10.34 & 63.49 & 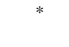 \\
\hline Condition Score & 0.69 & 0.69 & 0.70 & 0.71 & 0.71 & 0.72 & 0.71 & 0.69 & 0.16 & 0.71 & NS \\
\hline
\end{tabular}

G1 = Groundnut Hulls; G2 = Stover; G3 = Ground Nut Cake; G4 = Natural Grazing. a, b, c, d, and e = Values with different superscripts are significantly different; Values with similar superscripts are not significantly different. ${ }^{*}=$ significant at $(\mathrm{P}<0.05) ;{ }^{* *}=$ significant at $(\mathrm{P}<0.01){ }^{* * * *}=$ significant at $(\mathrm{P}<0.001)$.

Table 3. Body traits performance of type of sex and age group effect.

\begin{tabular}{|c|c|c|c|c|c|c|c|c|c|c|}
\hline \multirow{2}{*}{$\begin{array}{l}\text { Performance Traits } \\
\qquad(\mathrm{cm})\end{array}$} & \multicolumn{2}{|c|}{ Sex } & \multirow{2}{*}{ LSD } & \multicolumn{4}{|c|}{ Age Group } & \multirow{2}{*}{ LSD } & \multirow{2}{*}{ SEM } & \multirow{2}{*}{$\begin{array}{c}\text { Overall } \\
\text { Mean }\end{array}$} \\
\hline & Male & Female & & Mature & Weaner & Yearling & $1-2.5 \mathrm{yr}$ & & & \\
\hline Heart Girth & $111.16^{\mathrm{b}}$ & $115.98^{\mathrm{a}}$ & $* *$ & $121.89^{\mathrm{a}}$ & $108.05^{\mathrm{c}}$ & $116.02^{\mathrm{b}}$ & $115.72^{\mathrm{b}}$ & $* * *$ & 10.99 & 113.57 \\
\hline Body Length & $85.01^{\mathrm{b}}$ & $92.82^{\mathrm{a}}$ & $* * *$ & $100.13^{\mathrm{a}}$ & $83.40^{c}$ & $90.43^{\mathrm{b}}$ & $91.00^{\mathrm{b}}$ & $* * *$ & 13.64 & 88.94 \\
\hline Height & $105.88^{\mathrm{b}}$ & $111.51^{\mathrm{a}}$ & * & $117.28^{\mathrm{a}}$ & $105.84^{\mathrm{c}}$ & $106.38^{\mathrm{c}}$ & $109.80^{\mathrm{b}}$ & $* *$ & 11.43 & 108.71 \\
\hline Leg Length & $64.40^{\mathrm{b}}$ & $68.70^{\mathrm{a}}$ & $* * *$ & $72.63^{\mathrm{a}}$ & $63.84^{\mathrm{c}}$ & $67.43^{\mathrm{b}}$ & $67.21^{\mathrm{b}}$ & $* * *$ & 7.03 & 66.56 \\
\hline Neck Length & $39.16^{\mathrm{b}}$ & $41.49^{\mathrm{a}}$ & ** & $42.81^{\mathrm{a}}$ & $40.23^{b}$ & $39.43^{b}$ & $44.53^{\mathrm{a}}$ & * & 5.03 & 40.33 \\
\hline Dewlap Length & $60.18^{\mathrm{b}}$ & $66.77^{\mathrm{a}}$ & $* * *$ & $70.56^{\mathrm{a}}$ & $59.77^{\mathrm{c}}$ & $62.43^{\mathrm{b}}$ & $67.30^{\mathrm{a}}$ & $* * *$ & 10.34 & 63.50 \\
\hline Condition Score & 0.70 & 0.70 & NS & 0.70 & 0.69 & 0.71 & 0.71 & NS & 0.16 & 0.71 \\
\hline \multirow{2}{*}{$\begin{array}{l}\text { Performance Traits } \\
\text { (in } \mathrm{cm} \text { ) }\end{array}$} & \multicolumn{8}{|c|}{ Sex-Age Group Interaction } & \multirow[b]{2}{*}{ LSD } & \multirow[b]{2}{*}{ SEM } \\
\hline & $\begin{array}{c}\text { Male } \\
\text { Mature }\end{array}$ & $\begin{array}{c}\text { Male } \\
\text { Weaner }\end{array}$ & $\begin{array}{l}\text { Male } \\
\text { Yearling }\end{array}$ & $\begin{array}{c}\text { Male } \\
1-2.5 \mathrm{yr}\end{array}$ & $\begin{array}{l}\text { Female } \\
\text { Mature }\end{array}$ & $\begin{array}{l}\text { Female } \\
\text { Weaner }\end{array}$ & $\begin{array}{l}\text { Female } \\
\text { Yearling }\end{array}$ & $\begin{array}{c}\text { Female } \\
1-2.5 \mathrm{yr}\end{array}$ & & \\
\hline Heart Girth & $124.67^{\mathrm{a}}$ & $102.54^{\mathrm{c}}$ & $115.44^{\mathrm{b}}$ & $112.40^{\mathrm{b}}$ & $121.71^{\mathrm{a}}$ & $112.14^{\mathrm{b}}$ & $116.58^{\mathrm{b}}$ & $120.33^{\mathrm{a}}$ & * & 10.99 \\
\hline Body Length & 96.11 & 76.58 & 86.70 & 88.24 & 105.29 & 88.49 & 94.00 & 94.33 & NS & 13.60 \\
\hline Height & $106.28^{d}$ & $99.39^{c}$ & $112.44^{\mathrm{a}}$ & $106.28^{b}$ & $105.00^{\mathrm{b}}$ & $110.63^{b}$ & $112.33^{\mathrm{a}}$ & $114.67^{\mathrm{a}}$ & $*$ & 11.43 \\
\hline Leg Length & 70.78 & 60.46 & 66.09 & 64.64 & 75.00 & 66.74 & 58.71 & 70.78 & NS & 7.03 \\
\hline Neck Length & 41.33 & 39.00 & 38.34 & 34.24 & 44.71 & 44.14 & 40.42 & 42.33 & NS & 5.03 \\
\hline Dewlap Length & 68.44 & 54.50 & 58.70 & 64.48 & 73.29 & 63.69 & 66.04 & 71.22 & NS & 10.34 \\
\hline Condition Score & 0.69 & 0.68 & 0.72 & 0.72 & 0.71 & 0.70 & 0.72 & 0.72 & NS & 0.16 \\
\hline
\end{tabular}

a, b, and c $=$ Values on the same row with different superscripts differ significantly. NS = Not Significant; LSD = Least Significant Difference. ${ }^{*}=$ significant at $(\mathrm{P}<0.05) ;{ }^{* *}=$ significant at $(\mathrm{P}<0.01) ;{ }^{* * *}=$ significant at $(\mathrm{P}<0.001)$. 
spect to the parameters under study showed a highly significant difference $(\mathrm{P}<0.001)$ among the age group's types. Mature animals had better heart girth $(121.89 \mathrm{~cm})$ than yearlings $(116.02 \mathrm{~cm}), 1-2.5 \mathrm{yr}(115.72 \mathrm{~cm})$ and weaner's age groups $(108.05 \mathrm{~cm})$. Also as revealed by results sex-age group interaction with regards to the trait performance measurements, showed no significant differences in all possible types of interactions (Table 3).

Body weight changes with respect to age groups showed highly significant differences $(P<0.05)$ in initial and final body weights (Table 3). Mature animals showed better initial live body weight (148.71 Kg), than other age groups. Also this implies for final live body weight and body weight changes (Kg per month) among the age groups. There was no interaction between the feeding system and age groups interaction.

Both feeding systems and seasonal changes showed a significant $(\mathrm{P}<0.05)$ better performance in average live body weight, heart girth, height, and body length (Table 4) which reveals that supplementary feeding effect was significantly related to the body traits performance. In wet summer and in winter live body weights (174.56 and 174.20 Kg respectively), heart girth $(117.76$ and $117.50 \mathrm{~cm})$ and condition score (1.75 and 1.56) for G3 supplemented with groundnut cake was much better than dry summer performance in these parameters (Table 4).

\section{Discussion}

In the tropics and sub-tropics, stock keeping largely depends on the herbage yield of grazing lands, which is directly affected by the amount of the rainfall [11]. Intensive and continuous stocking reduced regrowth potentials and encourages inferior and less acceptable grasses in terms of quality. During dry season animals are allowed to spread out, scavenging for the sparse low quality grasses. Thus a marked loss in live weight changes, emaciation and as such loss in animal score condition occurs [12] [13]. In the present study, despite the fact that the animals were assigned to the same range vegetation type on dry summer, wet and winter grazing, the animals exhibited seasonal variations in their live body weight, heart girth and condition score, this could probably being

Table 4. Dry summer supplementary feeding and seasonal effects on body traits performance of Baggara cattle.

\begin{tabular}{|c|c|c|c|c|c|c|c|}
\hline \multirow{2}{*}{ Performance Traits } & \multicolumn{6}{|c|}{ Dry summer } & \multirow{2}{*}{ LSD } \\
\hline & \multicolumn{2}{|c|}{ G1 } & G2 & \multicolumn{2}{|c|}{ G3 } & G4 & \\
\hline Average Body Weight (Kg) & \multicolumn{2}{|c|}{$143.60^{\mathrm{b}}$} & $142.13^{b}$ & \multicolumn{2}{|c|}{$162.53^{\mathrm{a}}$} & $125.95^{\mathrm{c}}$ & * \\
\hline Heart Girth & \multicolumn{2}{|c|}{113.10} & 113.43 & \multicolumn{2}{|c|}{114.66} & 112.63 & NS \\
\hline Body Length & \multicolumn{2}{|c|}{$82.74^{\mathrm{b}}$} & $84.65^{\mathrm{b}}$ & \multicolumn{2}{|c|}{$95.37^{\mathrm{a}}$} & $94.89^{\mathrm{a}}$ & $*$ \\
\hline Height & \multicolumn{2}{|c|}{$108.57^{\mathrm{b}}$} & $103.82^{\mathrm{b}}$ & \multicolumn{2}{|c|}{$116.43^{\mathrm{a}}$} & $109.58^{\mathrm{a}}$ & $*$ \\
\hline Condition Score & \multicolumn{2}{|c|}{0.69} & 0.71 & \multicolumn{2}{|c|}{0.72} & 0.70 & NS \\
\hline & \multicolumn{6}{|c|}{ Wet Summer } & LSD \\
\hline Performance Traits & \multicolumn{2}{|c|}{ G1 } & G2 & \multicolumn{2}{|l|}{ G3 } & G4 & \\
\hline Average Body Weight (Kg) & \multicolumn{2}{|c|}{$163.50^{\mathrm{b}}$} & $158.71^{\mathrm{c}}$ & \multicolumn{2}{|l|}{$174.56^{\mathrm{a}}$} & $154.30^{\mathrm{d}}$ & * \\
\hline Heart Girth & \multicolumn{2}{|c|}{116.11} & 115.29 & \multicolumn{2}{|l|}{117.76} & 114.30 & NS \\
\hline Body Length & \multicolumn{2}{|c|}{$86.51^{\mathrm{b}}$} & $967.61^{b}$ & \multicolumn{2}{|l|}{$96.00^{\mathrm{a}}$} & $95.00^{\mathrm{a}}$ & $*$ \\
\hline Height & \multicolumn{2}{|c|}{$107.91^{\mathrm{c}}$} & $103.82^{d}$ & \multicolumn{2}{|l|}{$117.32^{\text {aa }}$} & $110.09^{\mathrm{b}}$ & * \\
\hline Condition Score & \multicolumn{2}{|c|}{$1.07^{\mathrm{b}}$} & $0.95^{\mathrm{c}}$ & \multicolumn{2}{|l|}{$1.75^{\mathrm{a}}$} & $0.72^{\mathrm{d}}$ & * \\
\hline \multirow{2}{*}{ Performance Traits } & \multicolumn{4}{|c|}{ Winter } & \multirow{2}{*}{ LSD } & \multirow{2}{*}{$\begin{array}{c}\text { Overall } \\
\left({ }^{-x}\right)\end{array}$} & \multirow{2}{*}{ SEM } \\
\hline & G1 & G2 & G3 & G4 & & & \\
\hline Average Body wt & $157.01^{\mathrm{b}}$ & $152.10^{\mathrm{c}}$ & $174.20^{\mathrm{a}}$ & $149.20^{\mathrm{d}}$ & * & 156.16 & 24.0 \\
\hline Heart Girth & 115.67 & 114.32 & 117.50 & 113.50 & NS & 114.85 & 0.99 \\
\hline Body Length & $86.09^{b}$ & $86.00^{\mathrm{b}}$ & $95.37^{\mathrm{a}}$ & $95.20^{\mathrm{a}}$ & $*$ & 90.45 & 18.94 \\
\hline Height & $106.35^{\mathrm{c}}$ & $105.82^{\mathrm{c}}$ & $116.48^{\mathrm{a}}$ & $110.51^{\mathrm{b}}$ & * & 109.65 & 7.03 \\
\hline Condition Score & $1.00^{\mathrm{b}}$ & $0.92^{\mathrm{c}}$ & $1.56^{\mathrm{a}}$ & $0.70^{\mathrm{a}}$ & $*$ & 0.97 & 0.70 \\
\hline
\end{tabular}

a, b, and c = values on the same row with different superscripts differ significantly. ${ }^{*}(\mathrm{P}<0.05)$; NS = Not Significant; LSD = Least Significant Difference; SEM = Stander Error. G1 = Groundnut Haulm; G2 = Stover; G3 = Groundnut Cake; G4 = Natural Grazing. 
attributed to the fact that groundnut cake has a higher percentages of protein (35.5\%) when compared to groundnut haulms (8.1\%), Stover (4.2\%) and range grasses (4.9\%), as reported by [14]. This is in line with [15] who reported an increase in body live weight of beef cattle as dry summer supplementation of leguminous grasses. On the other hand, those groups of animals supplemented with Stover, are more or less equal in average weights to natural grazing group with no supplementation.

The body traits measurements, heart girth, height, and condition score were not significantly affected by seasonal changes or feeding system. This is likely to be due to the fact that, the experimental animals are not uniform in age-groups. In the groundnut cake supplemented groups perform better than other groups in body length and height. This agrees with [16] that the intake of tropical grass may decline remarked ably when crude protein percentage goes below 6\%. This leads to sub-optimum level of nitrogen for the rumen flora, which requires an increase in the amount of feed ingested for improvement of animal performance when grazing such forages to maintain better performance [17].

The season affected the average live body weight, heart girth, and condition score examined in this study. However the magnititude of those seasonal effects were attributed to nutritional status of grassland. In wet summer, the average body weight, heart girth, and condition score, showed the best performance than in the cool winter season, which comes next, then dry summer with its supplementary feeding effects in terms of body weight gain improvement. This due to the fact that during the rainy season, the range vegetation is well established and the protein content is significantly high when compared with other two seasons. In winter, the fiber content of the range species progressively increases and the protein content reduces towards the drier season. That is, why there is a progressive loss in body weight and condition score towards the dry season in summer. Thus the performance in average body weight, heart girth and condition score during the wet summer progressively increase as a compensatory growth, with a slight decline in weight and condition score towards the cool season as pasture value decline. This finding goes with view that when the dry season begins the animal experiences a period weight loss, before the onset of the next favorable season i.e. autumn [18]. This is agrees with the finding of [2] and [19] who found that, animal weight gains are usually higher in the wet season when grasses are young, but in the dry season, when pasture growth stops and quality declines, animal weights also decline.

\section{Conclusion}

It can be concluded that, the dry summer supplementary feeding is only able to raise up the cattle performance to their performance during winter season, that is, in terms of average weight obtained, weight change, heart girth and condition score. The supplemented groups during summer developed a high compensatory growth rate during wet summer, as average weight, and body condition tends to increase when pasture is green, and show a decline trends by the onset of summer when grasses value reduces.

\section{Acknowledgements}

This study was supported by a grant-in-aid from University of Juba and the Former Directorate of Animal Resources Research Cooperation, Khartoum, Sudan.

\section{References}

[1] Bastos, E. (2013) Multi-Stakeholder Action for Sustainable Livestock, Side-Event at the 38th FAO Conference. Brazilian Roundtable on Sustainable Livestock. FAO, Rome.

http://www.livestockdialogue.org/fileadmin/templates/res_livestock/docs/2013_june17_Rome/GTPS_FAO_Jun13_Inst itutional-eng.pdf

[2] Walker, B. and Scot, J.D. (1997) Grazing Experiment at Ukiriguru, Tanzania III. A Comparison of Three Stocking Rates on the Productivity and Botanical Composition of Natural Pastures of Hard Pan Soils. East African Agricultural and Forestry Journal, 34, 245-255.

[3] FAO (2013) Optimization of Feed Use Efficiency in Ruminant Production Systems-Proceedings of the FAO Symposium, 27 November 2012, Bangkok, Thailand. In: Harinder, P.S. and Beeve, M.D., Eds., FAO Animal Production and Health Proceedings, No. 16, FAO and Asian-Australasian Association of Animal Production Societies, Rome, 225250.

[4] Keady, T.W.J., Marley, C.M. and Scollan, N.D. (2012) Grass and Alternative Forage Silages for Beef Cattle and Sheep: 
Effects on Animal Performance. Proceedings of the 16th International Silage Conference, Hämeenlinna, Katherine Region, 28th August 2012, 112-128.

[5] Nicholson, M.J. and Butterworth, M.H. (1986) A Guide to Condition Scoring of Zebu Cattle. International Livestock Centre for Africa, Addis Ababa.

[6] Nicholson, M.J. and Sayers, A.N.R. (1986) Relationship between Body Weight, Condition Score and Heart Girth Changes in Boran Cattle. Tropical Animal Production, 23, 123-127.

[7] Van Niekerk, A. and Low, B.P. (1980) Condition Scoring of Beef Cattle Bulletin N2/80. Department of Agriculture and Fisheries, Natal Region, South Africa.

[8] FAO (1996) World Livestock Production Systems: Current Status, Issues and Trends. In: Seré, C. and Steinfeld, H., Eds., FAO Animal Production and Health Paper 127, FAO, Rome, 181-197.

[9] Voekl Kristin, E. and Gerber, S.B. (1998). Using SPSS for Windows. Data Analysis and Graphics 1998.

[10] Duncan, D.B. (1955). Multiple Range and Multiple F-Tests. Biometrics, 11, 1-42. http://dx.doi.org/10.2307/3001478

[11] Ali, A.D. (1975) Carrying Capacity Assessment under the Annual Range Type of the Savanna. Proceeding of the 7th Sudan Veterinary Association Conference, Khartoum, 17th October 1975, 97-105.

[12] Ahmed, F.A. and Ahmed, A.E. (1978) Plant Cover, Nutritive Value and Carrying Capacity of a Range Pasture in the Low Rainfall Woodland Savanna of Western Sudan. East Africa for J. Agric., 43, 238-245.

[13] FAO (2010) Agriculture, Food Security and Climate Change in the Post-Copenhagen Process, an FAO Information Note. FAO, Rome.

[14] Sulieman, Y.R. and Mabrouk, A.A. (1998) The Nutrient Composition of Sudanese Animal Feeds. Central Animal Nutrition Lab, Animal Production Research Centre Bull. No. iii, Khartoum.

[15] Norman, M.J.T. (1996) Grazing and Feeding Trials with Beef Cattle in Katharine N. T. CSIRO Aust. Division of Land Research and Regional Survey Technical Paper No. 12, Centre for Soil Inquiry and Range Optimization, Rome.

[16] Manninen, M., Honkavaara, M., Jauhiainen, L., Nykänen, A. and Heikkilä, A.M. (2011) Effects of Grass-Red Clover Silage Digestibility and Concentrate Protein Concentration on Performance, Carcass Value, Eating Quality and Economy of Finishing Hereford Bulls Reared in Cold Conditions. Agricultural and Food Science, 20, 151-168.

[17] Oosting, S.J., Mekoya, A., Fernandez-Rivera, S. and van der Zijpp, A.J. (2011) Sesbania sesban as a Fodder Tree in Ethiopian Livestock Farming Systems: Feeding Practices and Farmers’ Perceptions of Feeding Effects on Sheep Performance. Livestock Science, 139, 135-141. http://dx.doi.org/10.1016/j.livsci.2011.03.009

[18] Crowder, L.V. and Chedda, H.R. (1982) Herbage Quality and Grass Nutritive Value. Tropical Grassland Husbandry. Longman Inc., New York, 349.

[19] Steen, R.W.J. (1987) Factor Affecting the Utilization of Grass Silage for Beef Production. In: Frame, J.F., Ed., Efficient Beef Production from Grass. Occasional Symposium of the British Grassland Society, Vol. 22, Berkshire, England, 129-139. 
Scientific Research Publishing (SCIRP) is one of the largest Open Access journal publishers. It is currently publishing more than 200 open access, online, peer-reviewed journals covering a wide range of academic disciplines. SCIRP serves the worldwide academic communities and contributes to the progress and application of science with its publication.

Other selected journals from SCIRP are listed as below. Submit your manuscript to us via either submit@scirp.org or Online Submission Portal.
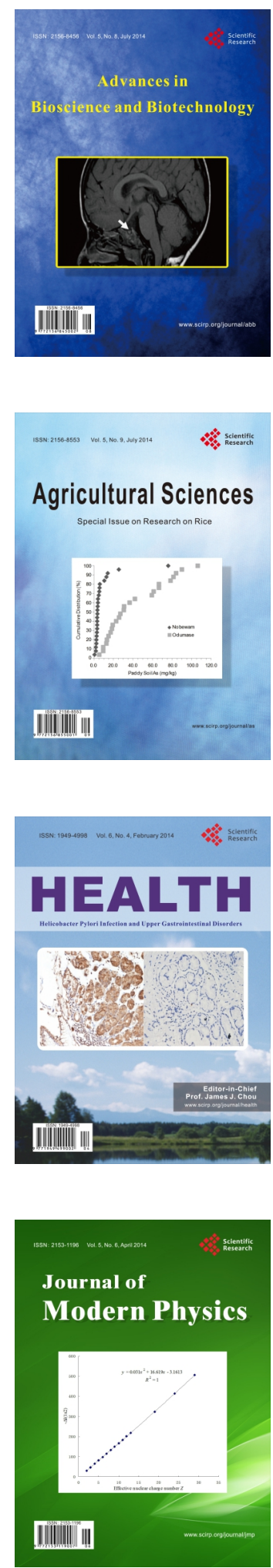
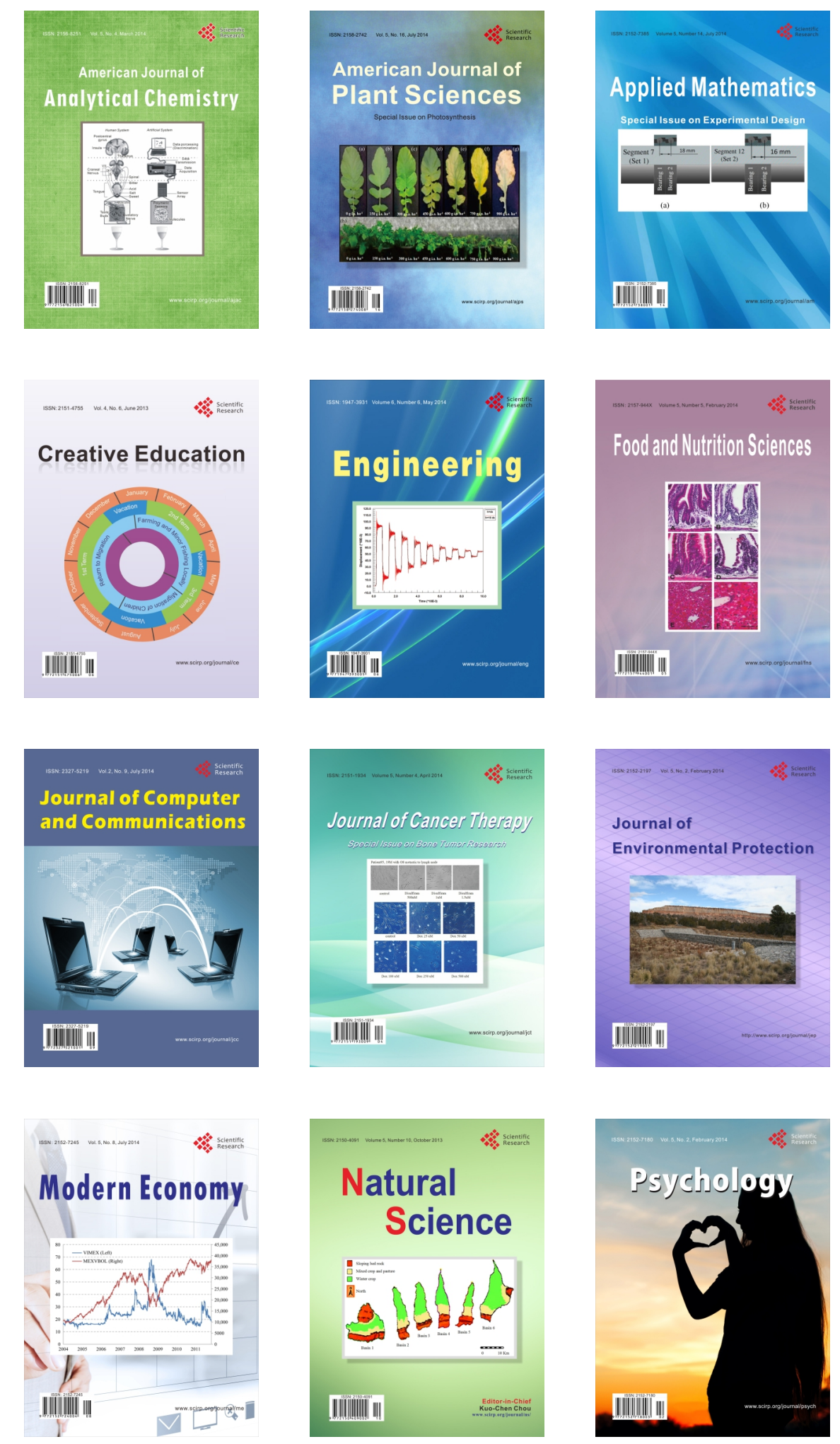